\title{
AGRONOMIC PERFORMANCE OF CARROT FERTILIZED WITH ROOSTERTREE [Calotropis procera (AIT.) R. BR.] IN TWO GROWING SEASONS
}

\author{
DESEMPENHO AGRONÔMICO DA CENOURA ADUBADA COM FLOR-DE-SEDA \\ [Calotropis procera (AIT.) R. BR.] EM DUAS ÉPOCAS DE CULTIVO
}

\author{
Almir Rogerio Evangelista de SOUZA ${ }^{1}$; Ênio Gomes Flôr SOUZA $^{1,2}$; \\ Manoel Galdino dos SANTOS ${ }^{1}$; Euvaldo Pereira de CERQUEIRA JÚNIOR ${ }^{3}$; \\ Rafaela Félix da FRANÇA ${ }^{4}$; Aurélio Paes BARROS JÚNIOR ${ }^{1}$; \\ Lindomar Maria da SILVEIRA ${ }^{1}$; Francisco BEZERRA NETO ${ }^{1}$
}

1. Pós-Graduação em Fitotecnia da Universidade Federal Rural do Semi-Árido - UFERSA, Mossoró, RN, Brasil.; 2. Instituto Federal de Alagoas - IFAL, Piranhas, AL, Brasil, enio.souza @ifal.edu.br; 3. Pós-Graduação em Engenharia Agrícola da Universidade Federal do Vale do São Francisco - UNIVASF, Juazeiro, BA, Brasil; 4. Pós-Graduação em Produção Agrícola da Universidade Federal Rural de Pernambuco - UFRPE, Unidade Acadêmica de Garanhuns - UAG, Garanhuns, PE, Brasil.

\begin{abstract}
Because vegetables have a fast production cycle, they require fertilization in quantities and at ideal times to obtain maximum productivity, and green manure is an alternative practice to the use of mineral fertilizers. This study was conducted to evaluate the effects of different amounts of roostertree [Calotropis procera (Ait.) R. Br.] biomass and its incorporation times in two growing seasons, in the agronomic performance of carrots. The experiment was conducted on an experimental farm at the Universidade Federal Rural de Pernambuco (UFRPE) in the autumn-winter period (March-July 2012) and the spring-summer period (September-December 2012). The experimental design was a randomized block design with three replications. The treatments were arranged in a factorial $4 \mathrm{x} 4$ design; the first factor consists of four amounts of roostertree biomass (5.4, 8.8, 12.2 and $15.6 \mathrm{t} \mathrm{ha}^{-1}$ on a dry basis), and the second factor consists of four times of incorporation of this manure into the soil $(0,10,20$ and 30 days before sowing the carrots). The carrot cultivar used was Brasília. The following traits were evaluated: plant height, number of leaves per plant, root dry mass, total and commercial yield of roots. The best agronomic performance of carrot cultivar Brasília was found with the amount of roostertree biomass of $15.6 \mathrm{tha}^{-1}$, in the time of incorporation into the soil of 10 days before seeding. The cultivation in the autumn-winter showed higher total and commercial productivities of carrot roots fertilized with roostertree.
\end{abstract}

KEYWORDS: Daucus carota L. Green manure. Organic cropping. Agronomic efficiency.

\section{INTRODUCTION}

The carrot (Daucus carota L.) is a vegetable crop belonging to the Apiaceae family, of the group of tuberous roots, cultivated on a large scale in the Brazilian states of São Paulo, Minas Gerais and Bahia (CEPEA, 2016). The production of carrot in the Brazilian northeast region is still incipient, developed mainly by small family farmers through community gardens. Thus, carrots need to be imported from other regions to meet the growing demand, with a consequent increase in price. An efficient alternative to meet the existing demand in the state of Pernambuco, Brazil, is the use of the practice of green manure, which results in increased production and is available to small, medium-sized and large producers.

The use of green manure in production systems has favored the reduction of dependence on external inputs, and it is an important alternative to reduce the use of mineral fertilizers, manures and organic compounds (DINIZ et al., 2007). This practice has the advantage of improving the physical and chemistry quality of the soil and as a result, increasing productivity (VALICHESKI et al., 2012; SOUZA et al., 2016).

The roostertree [Calotropis procera (Ait.) $\mathrm{R}$. Br.] has emerged as one of the most promising species in the use as green manure, mainly in the Brazilian semiarid region. The adaptation of this legume to adverse conditions such as drought stress, heat or salt stress, its high production of dry biomass, about $40 \mathrm{t} \mathrm{ha}^{-1}$, vigorous regrowth after cutting and $\mathrm{C} / \mathrm{N}$ ratio less than $30: 1$, have justified the increased interest of agronomic researchers on roostertree use as green manure (SOUTO et al., 2008; ANDRADE FILHO, 2012). Research results have demonstrated the potential use of this specie as green manure in the radish crop (LINHARES et al., 2011), carrot (SILVA et al., 2013), coriander (LINHARES et al., 2014), arugula (SOUZA et al., 2016) and lettuce-arugula intercropping (ALMEIDA et al., 2015).

The positive effects of green manuring to cropping depend on a number of factors such as the biomass amount produced and release time of 
nutrients. In beetroot crop, the best agronomic performance was found in the amount of $15.6 \mathrm{t} \mathrm{ha}^{-1}$ of hairy woodrose [Merremia aegyptia (L.) Urb.] incorporated into the soil on the sowing day (SILVA et al., 2011), whereas for arugula, it occurred in the amount of $15.6 \mathrm{t} \mathrm{ha}^{-1}$ incorporated at 20 days before planting (SOUZA et al., 2016).

However, there is little information on the amount and incorporation time of the roostertree biomass for carrot cultivation in the Brazilian semiarid region. Information on agronomical indicators of the use of roostertree as green manure can contribute to greater productive efficiency of agroecosystems with tuberous. The aim of this study was to evaluate the effects of different amounts of roostertree biomass and its incorporation times in two growing seasons (autumn-winter, springsummer) in the agronomic performance of carrots.

\section{MATERIAL AND METHODS}

\section{Cropping site and experimental conditions}

The experiment was conducted in two growing seasons, autumn-winter (March-July 2012) and spring-summer (September-December 2012) in experimental farm at the Universidade Federal Rural Pernambuco (UFRPE), in Serra Talhada, Pernambuco state, Brazil. Figure 1 shows the average meteorological data of the conducting period of the experiments.

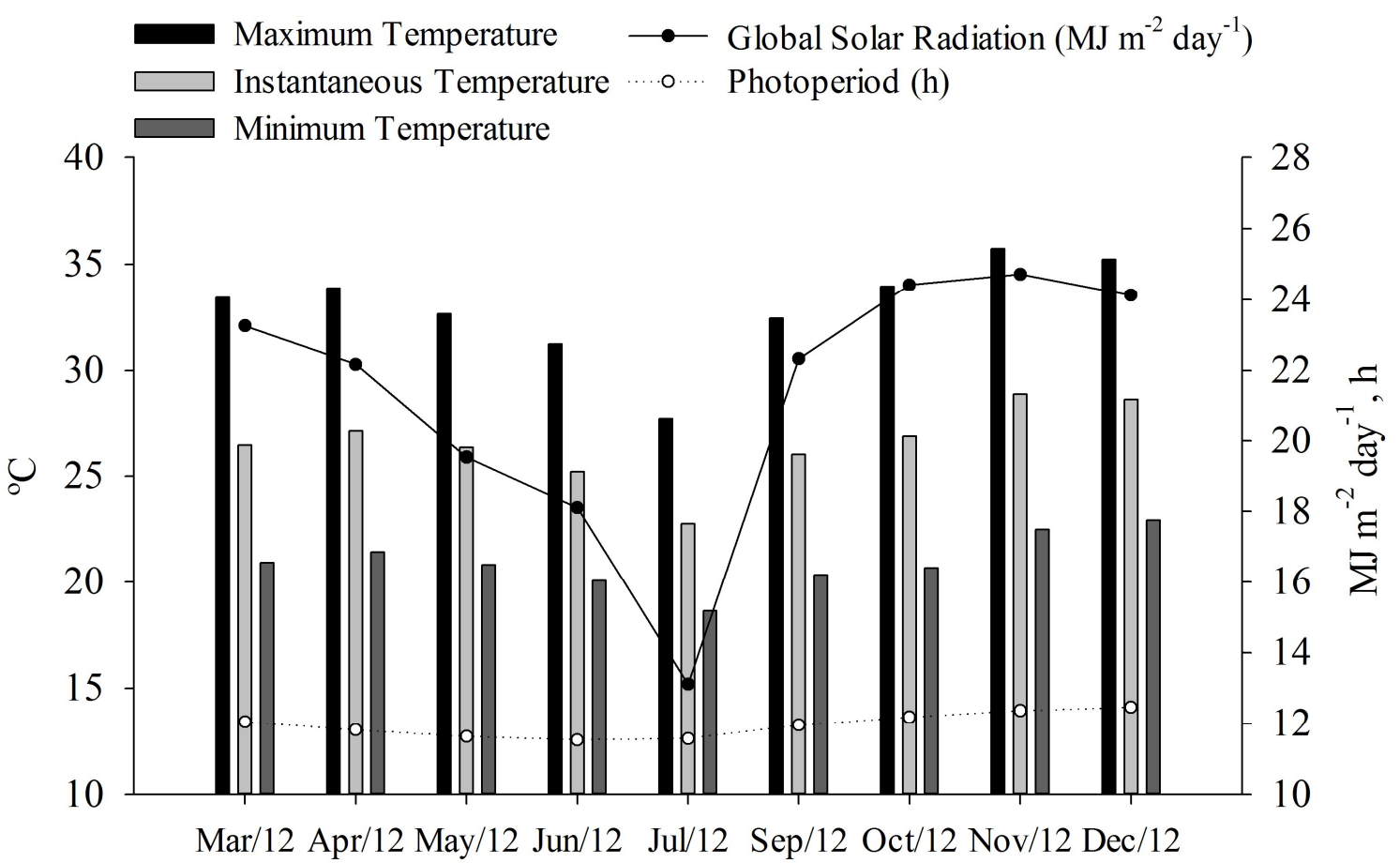

Figure 1. Average values of instantaneous, maximum and minimum temperatures $\left({ }^{\circ} \mathrm{C}\right)$, global solar radiation $\left(\mathrm{MJ} \mathrm{m}^{-2} \mathrm{day}^{-1}\right)$ and photoperiod (h) in each carrot growing season.

Prior to the experiment setup, soil samples were taken (sandy loam texture) at a depth of 0-0.20 $\mathrm{m}$, whose chemical characteristics in the autumnwinter experiment were: $\mathrm{pH}$ in $\mathrm{H}_{2} \mathrm{O}(1: 2.5)=6.5$; M.O. $=12.7 \mathrm{~g} \mathrm{~kg}^{-1} ; \mathrm{P}=20.0 \mathrm{mg} \mathrm{dm}$ (Mehlich: $\left.\mathrm{HCl}+\mathrm{H}_{2} \mathrm{SO}_{4}\right) ; \mathrm{K}^{+}=0.4 \mathrm{cmol}_{\mathrm{c}} \mathrm{dm}^{-3} ; \mathrm{Ca}^{2+}=3.4 \mathrm{cmol}_{\mathrm{c}}$ $\mathrm{dm}^{-3} ; \mathrm{Mg}^{2+}=2.0 \mathrm{cmol}_{\mathrm{c}} \mathrm{dm}^{-3} ; \mathrm{Al}^{3+}=0.0 \mathrm{cmol}_{\mathrm{c}} \mathrm{dm}^{-3}$; and spring-summer: $\mathrm{pH}$ in $\mathrm{H}_{2} \mathrm{O}(1: 2.5)=6.6$; M.O. $=8.4 \mathrm{~g} \mathrm{~kg}^{-1} ; \mathrm{P}=15.0 \mathrm{mg} \mathrm{dm}$ (Mehlich: $\left.\mathrm{HCl}+\mathrm{H}_{2} \mathrm{SO}_{4}\right) ; \mathrm{K}^{+}=0.6 \mathrm{cmol}_{\mathrm{c}} \mathrm{dm}^{-3} ; \mathrm{Ca}^{2+}=3.4 \mathrm{cmol}_{\mathrm{c}}$ $\mathrm{dm}^{-3} ; \mathrm{Mg}^{2+}=2.0 \mathrm{cmol}_{\mathrm{c}} \mathrm{dm}^{-3} ; \mathrm{Al}^{3+}=0.0 \mathrm{cmol}_{\mathrm{c}} \mathrm{dm}^{-3}$.

The experimental design was a randomized block design with three replications. The treatments were arranged in a factorial $4 \times 4$ design, with the first factor consisting of four amounts of roostertree biomass $\left(5.4,8.8,12.2\right.$ and $15.6 \mathrm{t} \mathrm{ha}^{-1}$ on a dry basis), and the second factor, of four times of incorporation of this manure into the soil $(0,10,20$ and 30 days before sowing carrot - DBS).

The carrot cultivar planted was Brasília, recommended for cultivation throughout the year in the Northeast (PIMENTEL; LANA; DE-POLLI, 2009). The seeding was performed directly in the definitive beds, where six planting lines were arranged transversely in each plot spaced at $0.20 \mathrm{~m}$ from each other, and spaced at $0.10 \mathrm{~m}$ within the line. The total area of the plot was $1.44 \mathrm{~m}^{2}$, with harvest area of $0.80 \mathrm{~m}^{2}$, resulting in a population of 500,000 plants ha $^{-1}$. 
The roostertree was collected only once in the vicinity of the experimental area, then ground in a traditional forage machine to yield fragments of two or three centimeters which were dried until a $10 \%$ moisture content. The material was analyzed, and presented the following results of nutrient contents in the dry matter at $70{ }^{\circ} \mathrm{C}: \mathrm{N}=17.4 \mathrm{~g} \mathrm{~kg}^{-1}$; $\mathrm{P}=4.4 \mathrm{~g} \mathrm{~kg}^{-1} ; \mathrm{K}=23.5 \mathrm{~g} \mathrm{~kg}^{-1} ; \mathrm{Ca}=14.3 \mathrm{~g} \mathrm{~kg}^{-1} ; \mathrm{Mg}$ $=23.0 \mathrm{~g} \mathrm{~kg}^{-1} ; \mathrm{Fe}=463.0 \mathrm{mg} \mathrm{kg}^{-1}, \mathrm{Zn}=40.0 \mathrm{mg} \mathrm{kg}$ ${ }^{1} ; \mathrm{Cu}=29.0 \mathrm{mg} \mathrm{kg}^{-1} ; \mathrm{Mn}=90.0 \mathrm{mg} \mathrm{kg}{ }^{-1} ; \mathrm{B}=71.0$ $\mathrm{mg} \mathrm{kg}^{-1} ; \mathrm{Na}=1,640.0 \mathrm{mg} \mathrm{kg}^{-1}$, M.O. $=764.0 \mathrm{mg} \mathrm{kg}^{-}$ ${ }^{1} ; \mathrm{C}: \mathrm{N}=25: 1$.

The incorporation of plant biomass was held in the $0-0.20 \mathrm{~m}$ layer of soil in the experimental plots, according to the treatments. There was no mineral fertilization. The irrigations were carried out by a micro sprinkler system, with daily watering schedule divided in two applications (morning and afternoon), providing a water slide of approximately $8 \mathrm{~mm} \mathrm{dia}^{-1}$.

Planting of carrot in the first growing season (autumn-winter) was held on March 29, 2012, while in the spring-summer it was performed on October 24, 2012. Direct seeding was carried out at two centimeters depth, sowing three seeds per hole. After ten days of the emergence the thinning occurred, leaving one plant per hole. Hand weedings were performed at 20 days after sowing (DAS). Theres was no pests or diseases control.

\section{Harvesting and evaluated variables}

The harvest in the autumn-winter period was performed at $96 \mathrm{DAS}$, while in spring-summer, at 89 DAS. The following characteristics were evaluated at harvest time: plant height, in $\mathrm{cm}$, calculated with a measuring ruler in a sample of twenty plants from the ground level up to the tip of the highest leaf; number of leaves per plant was determined in a sample of twenty plants by direct counting of the number of leaves larger than three centimeters in length, starting from the basal leaves up to the last open leaf; root dry mass, estimated from the weight of the root dry mass of twenty plants of the harvest area, after drying in a forced air oven, with temperature set at $65^{\circ} \mathrm{C}$, until constant mass, and expressed in $\mathrm{tha}^{-1}$.

The total and commercial productivity of carrot roots were calculated from the fresh mass of 40 roots of the harvest area of the plot, expressed in $\mathrm{t} \mathrm{ha}^{-1}$. They were considered as commercial productivity, roots free of defects, such as cracks, bifurcations, nematodes and mechanical damage.

\section{Statistical analysis}

Variance analyses were made for the evaluated characteristics, where corrections were applied to $70 \%$ of planted effectively area through the SISVAR 3.01 software (FERREIRA, 2003). A joint analysis of these characteristics was performed. Fitting procedures of response curves was done between traits and quantitative factors through the SigmaPlot 12.0 software (SYSTAT SOFTWARE, 2011). Tukey's test $(\mathrm{p}<0.05)$ was used to compare means between growing seasons.

\section{RESULTS AND DISCUSSION}

The joint analysis of the experiments found isolated effects of the amounts of roostertree biomass on plant height, root dry weight, commercial and total productivity of carrot roots (Figure 2). These features increased as increasing doses of roostertree were incorporated into the soil, reaching maximum values in the amount of $15.6 \mathrm{t}$ $\mathrm{ha}^{-1}$ green manure, representing an increase of 6.21 $\mathrm{cm}$ in plant height (Figure 2A);0.51 t ha ${ }^{-1}$ of root dry mass (Figure 2B); $6.56 \mathrm{t} \mathrm{ha}^{-1}$ in total root productivity (Figure 2C) and $4.09 \mathrm{t} \mathrm{ha}^{-1}$ in commercial productivity of carrots (Figure 2D) compared to the lower amount of roostertree in use $\left(5.4 \mathrm{tha}^{-1}\right)$.

The explanation for the performance achieved is plausible in nutrient availability, mainly $\mathrm{N}$ in assimilable form and at the time of highest demand of the plant, optimizing growth and crop productivity (BATISTA, 2011). Nitrogen is part of various compounds in the plant (amino acids, proteins, chlorophyll molecules, etc.) promoting plant growth and synthesis of new cells and tissues; it represents the nutrient more extracted and required by vegetable crops (CANTARELLA, 2007; PRADO, 2009; SILVA et al., 2013; GÓES et al., 2014). It is also reported to influence the upward increase of colony forming units, mostly bacteria, actinomycetes and fungi indispensable for the chemical and physical-chemical characteristics of the soil, aiding in fertility, decomposition of complex organic compounds, and reduction of variation in humidity and soil temperature, which are obtained with the incorporation of increasing doses of green manure (SCHIPPERS; BAKKER; BAKKER, 1987; SOUZA et al., 2005; ARAÚJO; MONTEIRO, 2007; BATISTA et al., 2016).

In the literature, research results report the importance of green manuring with spontaneous species of Caatinga. Oliveira et al. (2011), working with the same carrot cultivar of this study, fertilized with hairy woodrose under edaphoclimatic 
conditions of Mossoró (RN), had lower results for plant height $(0.42 \mathrm{~cm})$ and commercial productivity
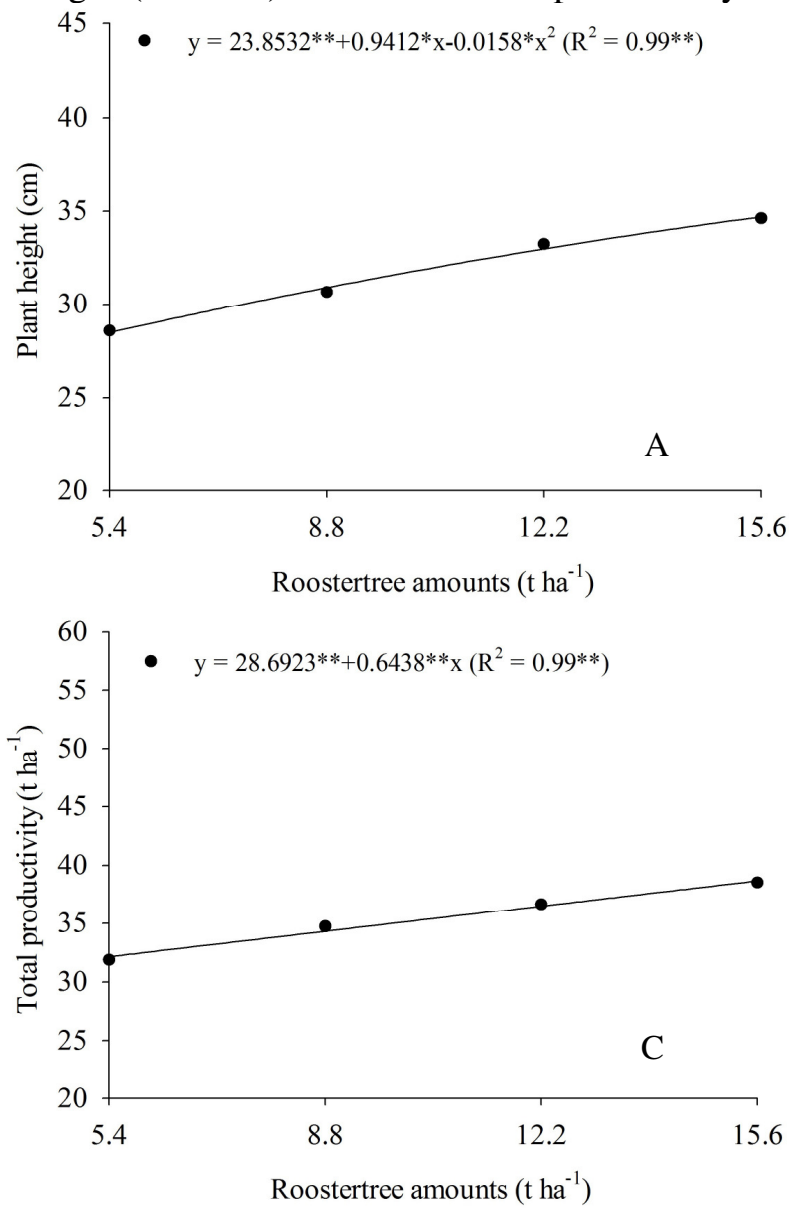

Figure 2. Plant height (A), root dry mass (B), total (C) amounts of roostertree biomass.

The number of leaves per plant and root dry mass of carrot were influenced in isolation by times of incorporation into the soil of the roostertree (Figure 3). The increase in the incorporation time of the green manure caused a linear decrease in the $\left(0.36 \mathrm{t} \mathrm{ha}^{-1}\right)$ per incorporated tonne.
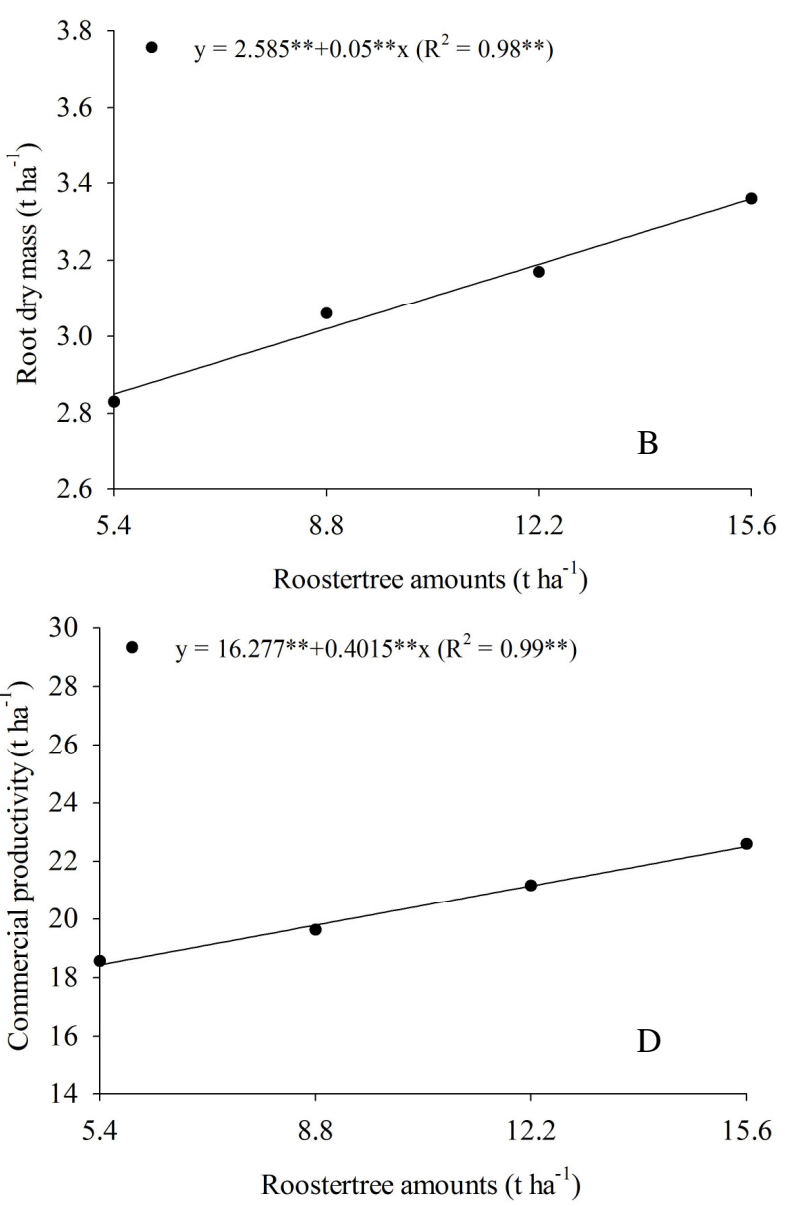

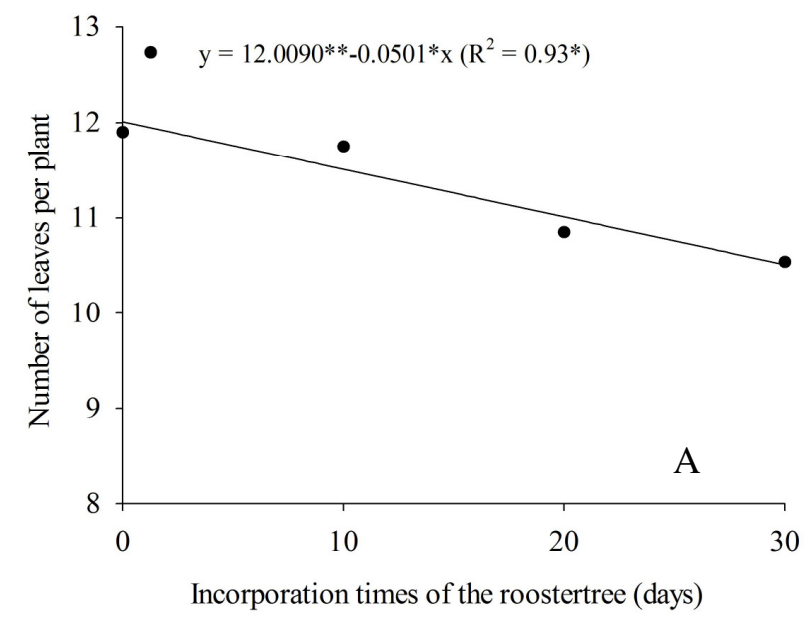

number of leaves per carrot plant (Figure 3A), whereas there was no fit of regression curve to root dry mass, whose observed average value was $3.11 \mathrm{t}$ ha $^{-1}$ (Figure 3B).

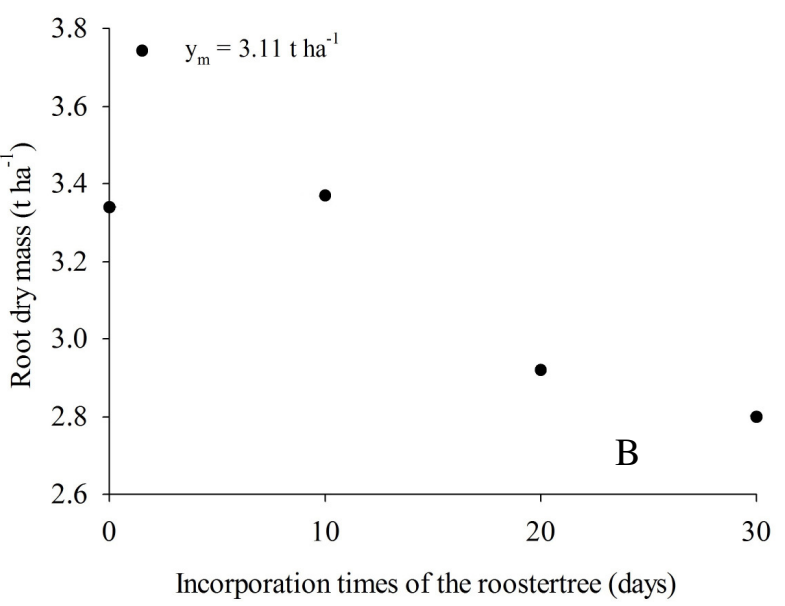

Figure 3. Number of leaves per plant (A) and dry mass (B) of carrot roots as a function of incorporation times into the soil of roostertree. 
El-Desuki et al. (2005) found a number of leaves and dry weight of radish roots enhanced with increasing levels of nitrogen fertilization. The incorporation of green manuring closest to the planting date favored the development of culture, due to be the ideal time between mineralization and availability of nutrients in the period of greatest nutritional demand of the culture. Cecílio Filho and Peixoto (2013) reported that nutrient accumulation in the Forto carrot cultivar has increased mainly from 35 days after sowing, more necessarily nitrogen. According to the findings of França, Reis and Cecílio Filho (2004), this essential nutrient is strongly associated with the development of plant structures; in this case, growth of shoots and roots. Oliveira et al. (2011), working with M. aegyptia in carrot crops, did not find a significant difference for number of leaves per plant as a function of incorporation times. A similar result was reported by Teófilo et al. (2009), when evaluating three carrot cultivars (Alvorada, Brasília and Esplanada) at 56 days after sowing. They did not find a significant difference for number of leaves in the conditions of Mossoró-RN.
There was a significant effect of growing seasons on root dry mass (Table 1), in which the crop reached a better result in the autumn-winter period $\left(4.85 \mathrm{tha}^{-1}\right)$ than in the spring-summer period $\left(1.37 \mathrm{t} \mathrm{ha}^{-1}\right)$. This likely occurred because of the influence of meteorological factors on the plants, which will mainly affect the distribution of water and nutrients in the soil profile, given that mild temperatures (autumn-winter) (Figure 1) contribute to better development of roots and dry matter accumulation in vegetable crops. Conditions of drought stress and high temperatures contribute to a reduction in photosynthetic activity and increased photorespiration in $\mathrm{C} 3$ plants especially (POLLEY, 2002; FILGUEIRA, 2008; TAIZ; ZEIGER, 2013). Vieira and Pessoa (2008) reported that temperature is the most important factor for the production of roots and that carrot cultivars form larger roots and have better quality in temperatures up to $30{ }^{\circ} \mathrm{C}$; above that, the vegetative cycle of the plant is reduced affecting root development and dry matter content.

Table 1. Average values of dry mass of carrot roots fertilized with roostertree in two growing seasons.

\begin{tabular}{cc}
\hline Growing seasons & Root dry mass $\left(\mathrm{t} \mathrm{ha}^{-1}\right)$ \\
\hline Autumn-winter & $4.85 \mathrm{a}$ \\
Spring-summer & $1.37 \mathrm{~b}$ \\
\hline $\mathrm{F}$ & $1,797.80^{* * *}$ \\
\hline C.V. $(\%)$ & 12.95
\end{tabular}

Means followed by the same letter in the column do not differ by Tukey's test at $5 \%$ probability; ${ }^{\text {ns}}$ : No significantly different (p > 0.05$)$, **: Significantly different at the $1 \%$ probability level by $\mathrm{F}$ test $(\mathrm{p} \leq 0.05)$.

Regarding number of leaves, there was a significant interaction between the amount of incorporated roostertree and the carrot growing seasons, with a higher vegetative vigor in the autumn-winter period (12.5 leaves per plant), while in the spring-summer, linear effect was registered, reaching 11.4 leaves in the highest incorporated dose of biomass $\left(15.6 \mathrm{t} \mathrm{ha}^{-1}\right)$ (Figure 4 and Table 2). Probably, extrinsic factors such as variation of soil moisture, temperature, solar radiation, photoperiod, etc. (Figure 1) of the second growing season were the main factors that influenced the reduction in the number of leaves per plant. Schüppler et al. (1998) have reported that in change conditions of soil moisture, plants tend to alter their morphology, especially plant biomass, reducing the number of leaves per plant. Stress caused by high temperatures and solar radiation are agricultural problems in many areas of the world, and they result in a series of morpho-anatomical changes that lead to crop yield reduction and economic losses (WAHID et al., 2007)

As regards the interaction of incorporation times to soil of the roostertree within each planting season, the regressions relative to plant height, total and commercial productivities of roots in the autumn-winter period did not allow equation adjustment; average values were $39.45 \mathrm{~cm}, 47.22 \mathrm{t}$ $\mathrm{ha}^{-1}$ and $23.72 \mathrm{t} \mathrm{ha}^{-1}$, respectively. However, in the spring-summer period, the response of the analyzed variables decreased from the initial time of incorporation (Figure 5). In relation to the average values of plant height, total and commercial productivities of the unfolding of the interaction of the growing seasons as a function of the incorporation times to soil of the roostertree, the average results achieved in the autumn-winter season were at $10 \mathrm{DBS}, 41.87 \mathrm{~cm}, 53.62 \mathrm{t} \mathrm{ha}^{-1}$ and $27.38 \mathrm{tha}^{-1}$, respectively, i.e., they were statistically higher than the spring-summer cropping (Table 3). 


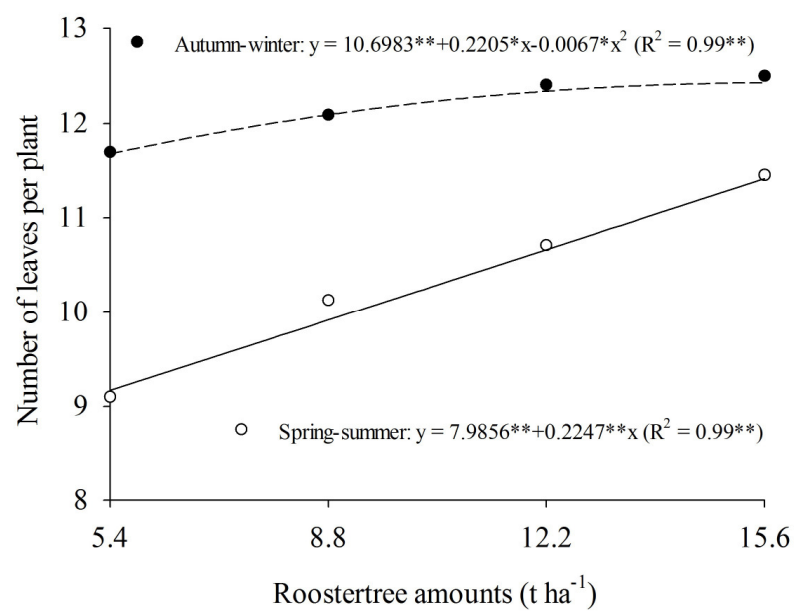

Figure 4. Number of leaves per carrot plant as a function of the unfolding of the interaction between amounts of roostertree biomass and growing seasons.

Table 2. Average values of number of leaves per carrot plant of the interaction between growing seasons as a function of the amounts of roostertree biomass.

\begin{tabular}{|c|c|c|c|c|}
\hline \multirow[t]{2}{*}{ Growing seasons } & \multicolumn{4}{|c|}{ Roostertree amounts $\left(\mathrm{t} \mathrm{ha}^{-1}\right)$} \\
\hline & 5.4 & 8.8 & 12.2 & 15.6 \\
\hline & \multicolumn{4}{|c|}{ Number of leaves per plant } \\
\hline Autumn-winter & $11.70 \mathrm{a}$ & $12.10 \mathrm{a}$ & $12.41 \mathrm{a}$ & $12.50 \mathrm{a}$ \\
\hline Spring-summer & $9.10 \mathrm{~b}$ & $10.12 b$ & $10.71 \mathrm{~b}$ & $11.45 \mathrm{~b}$ \\
\hline $\mathrm{F}$ & \multicolumn{4}{|c|}{$2.84 *$} \\
\hline C.V. $(\%)$ & \multicolumn{4}{|c|}{8.32} \\
\hline
\end{tabular}

Means followed by the same letter in the column do not differ by Tukey's test at $5 \%$ probability; ${ }^{\text {ns }}$ : No significantly different ( $\left.\mathrm{p}>0.05\right)$, *: Significantly different at the $5 \%$ probability level by $\mathrm{F}$ test $(\mathrm{p} \leq 0.05)$.
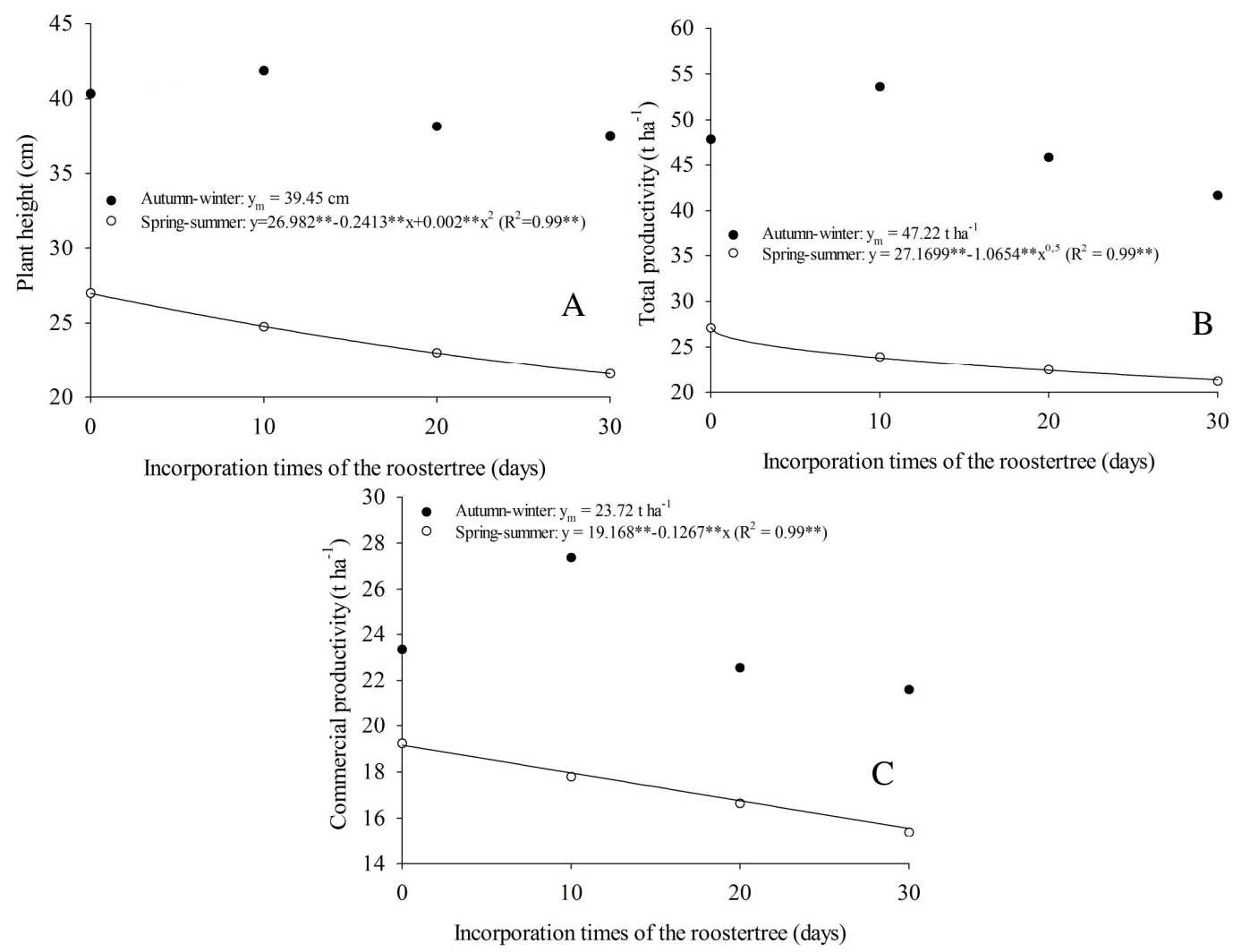

Figure 5. Plant height (A), total (B) and commercial productivities (C) of carrot roots as a function of the unfolding of the interaction of incorporation times to soil of roostertree within each growing seasons. 
Table 3. Average values of plant height, total and commercial productivity of carrot roots of the unfolding of the interaction of the growing seasons as a function of incorporation times into the soil of the roostertree.

\begin{tabular}{|c|c|c|c|c|}
\hline \multirow[t]{2}{*}{ Growing seasons } & \multicolumn{4}{|c|}{ Incorporation times of the roostertree (days) } \\
\hline & 0 & 10 & 20 & 30 \\
\hline & \multicolumn{4}{|c|}{ Plant height $(\mathrm{cm})$} \\
\hline Autumn-winter & $40.34 \mathrm{a}$ & $41.87 \mathrm{a}$ & $38.14 \mathrm{a}$ & $37.46 \mathrm{a}$ \\
\hline Spring-summer & $26.99 \mathrm{~b}$ & $24.75 \mathrm{~b}$ & $23.00 \mathrm{~b}$ & $21.58 \mathrm{~b}$ \\
\hline $\mathrm{F}$ & \multicolumn{4}{|c|}{$3.47 *$} \\
\hline C.V. $(\%)$ & \multicolumn{4}{|c|}{31.77} \\
\hline & \multicolumn{4}{|c|}{ Total productivity $\left(\mathrm{t} \mathrm{ha}^{-1}\right)$} \\
\hline Autumn-winter & $47.79 \mathrm{a}$ & $53.62 \mathrm{a}$ & $45.81 \mathrm{a}$ & $41.67 \mathrm{a}$ \\
\hline Spring-summer & $27.11 \mathrm{~b}$ & $23.91 \mathrm{~b}$ & $22.48 \mathrm{~b}$ & $21.21 \mathrm{~b}$ \\
\hline $\mathrm{F}$ & \multicolumn{4}{|c|}{$16.49 * *$} \\
\hline C.V. $(\%)$ & \multicolumn{4}{|c|}{7.34} \\
\hline & \multicolumn{4}{|c|}{ Commercial productivity $\left(\mathrm{t} \mathrm{ha}^{-1}\right)$} \\
\hline Autumn-winter & $23.34 \mathrm{a}$ & $27.38 \mathrm{a}$ & $22.55 \mathrm{a}$ & $21.60 \mathrm{a}$ \\
\hline Spring-summer & $19.24 \mathrm{~b}$ & $17.79 \mathrm{~b}$ & $16.64 \mathrm{~b}$ & $15.40 \mathrm{~b}$ \\
\hline $\mathrm{F}$ & \multicolumn{4}{|c|}{$3.01 *$} \\
\hline C.V. (\%) & \multicolumn{4}{|c|}{20.49} \\
\hline
\end{tabular}

Means followed by the same letter in the column do not differ by Tukey's test at 5\% probability; ${ }^{\text {ns }}$ : No significantly different ( $\mathrm{p}>0.05$ ), $* *$ and $*$ : Significantly different at the $1 \%$ and $5 \%$ probability levels by $\mathrm{F}$ test $(\mathrm{p} \leq 0.05)$.

The local meteorological conditions during the autumn-winter experiment (average temperature of $25.6{ }^{\circ} \mathrm{C}$, minimum of $20.4{ }^{\circ} \mathrm{C}$ and maximum of $31.8{ }^{\circ} \mathrm{C}$ ), when compared to spring-summer (average temperature of $27.6{ }^{\circ} \mathrm{C}$, minimum of 21.6 ${ }^{\circ} \mathrm{C}$ and maximum of $34.3{ }^{\circ} \mathrm{C}$ ) were essential for increasing productivity in the first growing season (Figure 1). A similar result was obtained by Resende, Yuri and Costa (2016) when evaluating the production of carrot cv. Brasília in winter and summer crops in the Submedia of the São Francisco Valley, Pernambuco.

In autumn-winter, there were higher total and commercial productivities, but the average percentage of scrap roots averaged $49.8 \%$ (Table 3 ). In the spring-summer period, non-commercial roots accounted for $27.3 \%$ of total productivity. This great difference between the total and commercial yields was due to the high incidence of nematodes, especially in autumn and winter, causing root defects such as galls, bifurcations and cracks (FILGUEIRA, 2008; NEVES et al., 2011). According to Pinheiro, Ferreira and Pereira (2012), these pathogens have greater soil activity and cause more severe damage to carrot roots during growing seasons with milder temperatures (autumn-winter) and in sandy soils, such as of the experimental area of the present work.

The narrow $\mathrm{C}: \mathrm{N}$ ratio situated in the range between 20 to $30: 1$ of the roostertree in the edaphoclimatic conditions of the semiarid region of Pernambuco allowed a rapid mineralization and release of nutrients (GÓES et al., 2011; ALMEIDA et al., 2015). Snyder et al. (2009) found that shoot mass, total and commercial productivity of carrots enhanced with increases in $\mathrm{N}$ availability, but they highlighted that the mineralization of other nutrients from plant biomass are essential to increase productivity. Production results obtained after 10 days of the incorporation of roostertree were similar to the average productivity in Brazil $\left(31.2 \mathrm{t} \mathrm{ha}^{-1}\right)$ and worldwide $\left(30.2 \mathrm{t} \quad \mathrm{ha}^{-1}\right)$ (EMBRAPA HORTALIÇAS, 2013; FAO, 2014).

Fageria (2007) points out that the influence of green manure can vary from soil to soil, culture to culture, environmental variables, type of crop and management. Linhares et al. (2011) evaluated the velocity of decomposition of roostertree biomass in radish cultivation, with treatments consisting solely of 0 time and 15 days of incorporation before sowing. They found that the greater residence time in soil of the manure promoted better agronomic performance for this vegetable crop. This same ideal time of incorporation was found by Linhares et al. (2009) in the production of arugula under fertilization with roostertree in pot conditions. The authors also attributed the rapid mineralization to low $\mathrm{C} / \mathrm{N}$ ratio of the evaluated plant material. In addition to this feature, it should be emphasized that constant irrigation and the occurrence of average temperatures above $25{ }^{\circ} \mathrm{C}$ (Figure 1) were also stimulating conditions for microbial activity in the soil. 


\section{CONCLUSIONS}

The better agronomic performance of carrot cv. Brasília was found with the amount of roostertree of $15.6 \mathrm{t} \mathrm{ha}^{-1}$, in the time of incorporation to the soil of 10 days before seeding.

Cultivation in autumn-winter provided higher total and commercial productivities of carrot roots with roostertree in the semiarid conditions of Pernambuco, Brazil.

\section{ACKNOWLEDGEMENTS}

Special thanks are due to the Fundação de Amparo à Ciência e Tecnologia do Estado de Pernambuco (FACEPE) for funding this research and granting novice reseaercher and Master's degree scholarships. We would also like to thank the Programa de Pós-Graduação em Produção Vegetal (PGPV) of the UFRPE for the support to all activities performed in this research.

RESUMO: As hortaliças, por possuírem ciclo rápido de produção, demandam adubações em quantidades e momentos ideais para a obtenção da máxima produtividade, sendo a adubação verde uma prática alternativa ao uso de fertilizantes minerais. O presente estudo foi realizado com o objetivo de avaliar os efeitos de diferentes quantidades de biomassa de flor-de-seda [Calotropis procera (Ait.) R. Br.] e seus tempos de incorporação, em duas épocas de cultivo, no desempenho agronômico da cenoura. $\mathrm{O}$ experimento foi conduzido em campo experimental pertencente à Universidade Federal Rural de Pernambuco (UFRPE), nos períodos outono-inverno (março a julho de 2012) e primavera-verão (setembro a dezembro de 2012). O delineamento experimental utilizado foi em blocos casualizados, com três repetições. Os tratamentos foram arranjados em esquema fatorial $4 \times 4$, com o primeiro fator constituído por quatro quantidades de biomassa de flor-de-seda $\left(5,4 ; 8,8 ; 12,2\right.$ e 15,6 tha ${ }^{-1}$ em base seca), e o segundo fator, por quatro tempos de incorporação ao solo deste adubo (0, 10, 20 e 30 dias antes da semeadura da cenoura - DAS). A cultivar de cenoura utilizada foi a Brasília. Foram avaliados a altura de plantas, número de folhas por planta, massa seca de raízes, produtividades total e comercial de raízes. O melhor desempenho agronômico da cenoura cv. Brasília foi obtido com a quantidade de flor-deseda de 15,6 t ha ${ }^{-1}$, no tempo de incorporação ao solo de 10 dias antes da semeadura. O cultivo no outono-inverno promoveu maiores produtividades total e comercial às raízes de cenoura adubada com flor-de-seda.

PALAVRAS-CHAVE: Daucus carota L. Adubo verde. Cultivo orgânico. Eficiência agronômica.

\section{REFERENCES}

ALMEIDA, E. S. A.; BEZERRA NETO, F.; COSTA, L. R.; SILVA, M. L.; LIMA, J. S. S.; BARROS

JÚNIOR, A. P. Eficiência agronômica do consórcio alface-rúcula fertilizado com flor-de-seda. Revista Caatinga, Mossoró, v. 28, n. 3, p. 79-85, jul.-sep. 2015. https://doi.org/10.1590/1983-21252015v28n309rc

ANDRADE FILHO, F. C. Bicultivo de folhosas consorciadas com beterraba em função de adubação com flor-de-seda e densidades populacionais. 2012. 94 f. Tese (Doutorado em Fitotecnia) - Curso de PósGraduação em Fitotecnia, Universidade Federal Rural do Semi-Árido, Mossoró, 2012.

ARAÚJO, A. S. F.; MONTEIRO, R. T. R. Indicadores biológicos de qualidade do solo. Bioscience Journal, Uberlândia, v. 23, n. 3, p. 66-75, jul.-sep. 2007.

BATISTA, M. A. V. Adubação verde na produtividade, qualidade e rentabilidade de beterraba e rabanete. 2011. 123 f. Tese (Doutorado em Fitotecnia) - Curso de Pós-Graduação em Fitotecnia, Universidade Federal Rural do Semi-Árido, Mossoró, 2011.

BATISTA, M. A. V.; BEZERRA NETO, F.; SILVA, M. L.; AMBRÓSIO, M. M. Q.; CUNHA, J. L. X. L. Soilplant attributes and beet production influenced by fertilization with species of Brazilian Caatinga. Horticultura Brasileira, Vitória da Conquista, v. 34, n. 1, p. 31-38, jan.-mar. 2016. https://doi.org/10.1590/S0102053620160000100005

CANTARELLA, H. Nitrogênio. In: NOVAIS, R. F.; ALVAREZ, V. H.; BARROS, N. F.; FONTES, R. L. F.; CANTARUTTI, R. B.; NEVES, J. C. L. (Ed.). Fertilidade do solo. 2. ed. Viçosa: Sociedade Brasileira de Ciência do Solo, 2007. p. 375-470. 
CECÍlIO FILHO, A. B.; PEIXOTO, F. C. Acúmulo e exportação de nutrientes em cenoura 'Forto'. Revista Caatinga, Mossoró, v. 26, n. 1, p. 64-70, jan.-mar. 2013.

CEPEA. Centro de Estudos Avançados em Economia Aplicada. PIB do Agronegócio Brasileiro. Disponível em: <http://cepea.esalq.usp.br/pib/>. Acesso em: 26 oct. 2016.

DINIZ, E. R.; SANTOS, R. H. S.; URQUIAGA, S. S.; PETERNELLI, L. A.; BARRELLA, T. P.; FREITAS, G. B. Green manure incorporation timing for organically grown broccoli. Pesquisa Agropecuária Brasileira, Brasília, v. 42, n. 2, p. 199-206, feb. 2007. https://doi.org/10.1590/S0100-204X2007000200008

EL-DESUKI; M.; SALMAN, S. R.; EL-NEMR, M. A.; ABDEL-MAWGOUD, A. M. R. Effect of plant density and nitrogen application on the growth, yield and quality of radish (Raphanus sativus L.). Journal of Agronomy, Faisalabad, v. 4, n. 3, p. 225-229, 2005. https://doi.org/10.3923/ja.2005.225.229

EMBRAPA HORTALIÇAS. Situação das safras de hortaliças no Brasil - 2000-2011. Disponível em: <http://www.cnph.embrapa.br>. Acesso em: 19 mar. 2013.

FAGERIA, N. K. Green manuring in crop production. Journal of Plant Nutrition, v. 30, n. 5, p. 691-719, may 2007. https://doi.org/10.1080/01904160701289529

FAO. Food and Agriculture Organization of the United Nation. The state of food and agriculture: innovation in family farming. Rome: FAO, 2014. 139 p.

FERREIRA, D. F. Programa SISVAR: sistema de análise de variância. Versão 4.6 (Build 6.0). Lavras: DEX/UFLA, 2003.

FILGUEIRA, F. A. R. Novo Manual de Olericultura: agrotecnologia moderna na produção e comercialização de hortaliças. 3. ed. Viçosa: UFV, 2008. 421 p.

FRANÇA, T. F.; REIS, F. C.; CECÍLIO FILHO, A. B. Análise de crescimento em cenoura, cv. Brasília, cultivada na primavera, em Jaboticabal-SP. In: CONGRESSO BRASILEIRO DE OLERICULTURA, 44. , 2004, Campo Grande. Anais... Brasília: Horticultura Brasileira, 2004.

GÓES, S. B.; BEZERRA NETO, F.; LINHARES, P. C. F.; GÓES, G. B. D.; MOREIRA, J. N. Productive performance of lettuce at different amounts and times of decomposition of dry scarlet starglory. Revista Ciência Agronômica, Fortaleza, v. 42, n. 4, p. 1036-1042, oct.-dec. 2011. https://doi.org/10.1590/S180666902011000400028

GÓES, S. B.; SÁ, J. R.; DUDA, G. D.; BEZERRA NETO, F.; SILVA, M. L.; LINHARES, P. C. F. Changes in the $\mathrm{pH}$ and macronutrients in soil fertilized with hairy woodrose in different amounts and times of incorporation. Revista Caatinga, Mossoró, v. 27, n. 3, p. 1-10, jul.-sep. 2014.

LINHARES, P. C. F.; MARACAJÁ, P. B.; PEREIRA, M. F. S.; ASSIS, J. P.; SOUSA, R. P. Roostertree (Calotropis procera) under different amounts and periods of incorporation on yield of coriander. Revista Verde de Agroecologia e Desenvolvimento Sustentável, Pombal, v. 9, n. 3, p. 7-12, jul.-sep. 2014.

LINHARES, P. C. F.; SILVA, M. L.; BORGONHA, W.; MARACAJA, P. B.; SILVA, M. J. A. Velocidade de decomposição da flor-de-seda no desempenho agronômico da rúcula cv. Cultivada. Revista Verde de Agroecologia e Desenvolvimento Sustentável, Mossoró, v. 4, n. 2, p. 46-50, apr.-jun. 2009.

LINHARES; P. C. F.; SILVA, M. L.; PEREIRA, M. F. S.; BEZERRA, A. K. H.; PAIVA, A. C. C. Quantidades e tempos de decomposição da flor-de-seda no desempenho agronômico do rabanete. Revista Verde de Agroecologia e Desenvolvimento Sustentável, Mossoró, v. 6, n. 1, p. 168-173, jan.-mar. 2011. 
NEVES, W. S.; LOPES, E. A.; FERNANDES, R. H.; DALLEMOLE-GIARETTA, R.; PARREIRA, D. F. Nematoides na cultura da cenoura: sintomas, disseminação e principais métodos de controle. Belo Horizonte: EPAMIG, 2011. 4 p. (Circular Técnica, 133).

OLIVEIRA, M. K. T.; BEZERRA NETO, F; BARROS JÚNIOR, A. P.; LIMA, J. S. S.; MOREIRA, J. N. Desempenho agronômico da cenoura adubada com jitirana antes de sua semeadura. Revista Ciência Agronômica, Fortaleza, v. 42, n. 2, p. 364-372, apr.-jun. 2011. https://doi.org/10.1590/S180666902011000200015

PIMENTEL, M. S.; LANA, A. M. Q.; DE-POLLI, H. Rendimentos agronômicos em consórcio de alface e cenoura adubadas com doses crescentes de composto orgânico. Revista Ciência Agronômica, Fortaleza, v. 40, n. 1, p. 106-112, jan.-mar. 2009.

POLLEY, H. W. Implications of atmospheric and climatic change for crop yield and water use efficiency. Crop Science, v. 42, n. 1, p. 131-140, jan. 2002. http://doi.org/10.2135/cropsci2002.1310

PINHEIRO, J. B.; FERREIRA, A. D.; PEREIRA, R. B. Ocorrência e controle de nematoides em apiaceas. Brasília: Embrapa Hortaliças, 2012. 13 p. (Circular Técnica, 103).

PRADO, R. M. 500 Perguntas e respostas sobre nutrição de plantas. Jaboticabal: FCAV/GENPLANT, 2009. $108 \mathrm{p}$.

RESENDE, G. M.; YURI, J. E.; COSTA, N. D. Planting times and spacing of carrot crops in the São Francisco Valley, Pernambuco state, Brazil. Revista Caatinga, Mossoró, v. 29, n. 3, p. 587-593, jul.-sep. 2016. https://doi.org/10.1590/1983-21252016v29n308rc

SCHIPPERS, B.; BAKKER, A. W.; BAKKER, P. A. H. M. Interactions of deleterious and beneficial rhizosphere microorganisms and the effect of cropping practices. Annual Review Phytopathology, v. 25, n. 1, p. 339-358, sep. 1987. https://doi.org/10.1146/annurev.py.25.090187.002011

SCHUPPLER. U.; HE, P. H.; JOHN, P. C.; MUNNS, R. Effects of water stress on cell division and celldivision-cycle-2-like cell-cycle kinase activity in wheat leaves. Plant Physiology, v. 117, n. 2, p. 667-678, jun. 1998. https://doi.org/10.1104/pp.117.2.667

SILVA, M. L.; BEZERRA NETO, F. B.; LINHARES, P. C.; BEZERRA, A. K. H. Producão de cenoura fertilizada com flor-de-seda (Calotropis procera (Ait.) R. Br.). Revista Ciência Agronômica, Fortaleza, v. 44, n. 4, p. 732-740, oct.-dec. 2013. https://doi.org/10.1590/S1806-66902013000400009

SILVA, M. L.; BEZERRA NETO, F.; LINHARES, P. C. F., SÁ, J. R.; LIMA, J. S. S.; BARROS JÚNIOR, A. P. Produção de beterraba fertilizada com jitirana em diferentes doses e tempos de incorporação ao solo. Revista Brasileira de Engenharia Agrícola e Ambiental, Campina Grande, v. 15, n. 8, p. 801-809, aug. 2011. https://doi.org/10.1590/S1415-43662011000800006

SNYDER, A.; MORRA, M. J.; JOHNSON-MAYNARD, J.; THILL; D. C. Seed meals from Brassicaceae oilseed crops as soil amendments: influence on carrot growth, microbial biomass nitrogen, and nitrogen mineralization. HortScience, v. 44, n. 2, p. 254-361, apr. 2009.

SOUTO, P. C.; SOUTO, J. S.; MIRANDA, J. P.; SANTOS, R. V.; ALVES, A. R. Comunidade microbiana e mesofauna edáficas em solo sob caatinga no semi-árido da Paraíba. Revista Brasileira de Ciência do Solo, Viçosa, v. 32, n. 1, p. 151-160, jan.-feb. 2008. https://doi.org/10.1590/S0100-06832008000100015 
SOUZA, Ê. G. F.; SANTANA, F. M. S.; MARTINS, B. N. M.; SANTOS, M. G.; CERQUEIRA JÚNIOR, E. P.; BARROS JÚNIOR, A. P.; SILVEIRA, L. M.; BEZERRA NETO, F.; LINS, H. A.; ALBUQUERQUE, J. R. T. Agronomic response of arugula to green fertilization with rooster tree during two culture times. African Journal of Agricultural Research, v. 11, n. 48, p. 4931-4938, dec. 2016.

http://dx.doi.org/10.5897/AJAR2016.11762

SOUZA, P. A. D.; NEGREIROS, M. Z.; MENEZES, J. B.; BEZERRA NETO, F.; SOUZA, G. L. F. M.; CARNEIRO, C. R.; QUEIROGA, R. C. F. D. Características químicas de folhas de alface cultivada sob efeito residual da adubação com composto orgânico. Horticultura Brasileira, Brasília, v. 23, n. 3, p. 754-757, jul.sep. 2005. https://doi.org/10.1590/S0102-05362005000300013

SYSTAT SOFTWARE. SigmaPlot for Windows Version 12.0. San Jose: Systat Software Inc., 2011.

TAIZ, L.; ZEIGER, E. Fisiologia vegetal. 5. ed. Porto Alegre: ArtMed, 2013. 954 p.

TEÓFILO, T. M. S.; FREITAS, F. C. L.; NEGREIROS, M. Z.; LOPES, W. A. R.; ALVES, S. S. V. Crescimento de cultivares de cenoura nas condições de Mossoró-RN. Revista Caatinga, Mossoró, v. 22, n. 1, p. 168-174, jan.-mar. 2009.

VALICHESKI, R. R.; GROSSKLAUS, F.; STÜRMER, S. L. K.; TRAMONTIN, A. L.; BLAADE, E. S. A. S. Desenvolvimento de plantas de cobertura e produtividade da soja conforme atributos físicos em solo compactado. Revista Brasileira de Engenharia Agrícola e Ambiental, Campina Grande, v. 16, n. 9, p. 969977, sep. 2012. https://doi.org/10.1590/S1415-43662012000900007

VIEIRA, J. V.; PESSOA, H. B. S. V. Clima. In: VIEIRA, J. V.; PESSOA, H. B. S. V.; MAKISHIMA, N. (Ed.). Cenoura (Daucus carota). Disponível em:

$<$ https://sistemasdeproducao.cnptia.embrapa.br/FontesHTML/Cenoura/Cenoura_Daucus_Carota/clima.html>. Acesso em: 17 jan. 2017.

WAHID, A.; GELANI, S.; ASHRAF, M.; FOOLAD, M. R. Heat tolerance in plants: an overview.

Environmental and Experimental Botany, v. 61, n. 3, p. 199-223, dec. 2007.

https://doi.org/10.1016/j.envexpbot.2007.05.011 